\title{
Application of Silver Nanoparticles on Cephalosporium maydis In vitro and In vivo
}

\author{
N.S. El-Gazzar ${ }^{\#}$ and G.H. Rabie \\ Botany and Microbiology Department, Faculty of Science, Zagazig University, \\ Zagazig, Egypt.
}

\begin{abstract}
T IS NOTICEABLE that Cephalosporium maydis causes late wilt disease that is considered sole of the ultimate destructive diseases in Zea maize. The crop output is declined due to the infection riskiness raises. Silver nanoparticles (AgNPs) were prepared using a simple bio-reduction method, which is ecologically welcomed and cost-effective. In our investigation, the effect the antifungal activity of AgNPs was evaluated alone or combined with one of each two different fungicides on $C$. maydis in vitro and in vivo. An isolate of Aspergillus niger previously isolated and identified in our laboratory was used to induce AgNPs. The NPs production's undergone to optimization study for increasing AgNPs product besides its stability. AgNPs production after optimization showed very stable product compared with those before optimization conditions. A significant increase in the absorbance was noticed from 0.8OD into 1.25OD and the NPs size decreased from $19 \mathrm{~nm}$ into 9nm. In addition, TEM showed more obvious and clear AgNPs, in addition, a higher degree of stability and protein functional surface reactive groups at $(-29.3 \mathrm{mv})$ with single peak was revealed for six months. Under laboratory conditions, the higher rate of growth inhibition of C. maydis was obvious in case of using AgNPs either alone or combined with fungicides. Parallel results were found under greenhouse conditions where AgNPs caused a severe reduction in disease severity of $C$. maydis infected plants accounting (57.7\%) alone or combined with Maxim XL (75.5\%) or Vitavax (90\%). This research opens up new possibilities in the field of using AgNPs in plant disease treatment.
\end{abstract}

Keywords: Aspergillus niger, Cephalosporium maydis, Fungicides, Plant disease, Silver nanoparticles.

\section{Introduction}

Agriculture is considered the most basics for countries developing through improving their income level. Plant disease causes reduction in agricultural production every year and causes millions of dollars loss to control these plant diseases. In recent years, using pesticide for controlling plant disease resulted in many environmental hazards. Therefore, many researchers try to find an alternative method for pesticides as metal nanoparticles. Nanotechnology is characterized by the formation of particles with variable sizes, shapes, chemical compositions, that is entered in many applications. Although chemical and physical methods may produce pure and well-defined nanoparticles, these methods are just costly and critical to the habitat (Reddy et al., 2012). The use of biological inducers for nanoparticles formation represented as an urgent eco-friendly way instead of chemical and physical methods (Rabie et al., 2014).
Nanotechnology in plant pathology is a modern outline through several nanotechnological implementations. Early detection of plant diseases and pathogens are some of the possible key applications in plant pathology through detection of site-targeted delivery for nano-formulated agrochemicals, development of disease resistant plant varieties by nanomaterialmediated genetic transformation (Nair et al., 2010). There are many applications for AgNPs in medical sides (Singh et al., 2008 and Panacek et al., 2009). AgNPs effect on different phytopathogens (Jha et al., 2009 and Patel et al., 2014). AgNPs activity was evaluated against certain ascomycetous fungi (Liu et al., 2009, Solgi et al., 2009 and Sang -Woo et al., 2012).

The biotechnological applications as, biomineralization have been investigated as biofactory for several metallic nanoparticles production (Sastry et al., 1998). Although, the presence of synthetic metallic nanoparticles the

"Corresponding author email: mora_sola1212@yahoo.com

DOI: 10.21608 /ejm.2018.3452.1057

C2018 National Information and Documentation Center (NIDOC) 
using of bio-factory technology is considered as an urgent necessity for habitat (Al-Askar et al., 2013). Thus, the present investigation aims to green bio-synthesis of AgNPs by an isolate of $A$. niger that was previously isolated and identified in our laboratory. The study includes Optimization and Stability of the AgNPs to enlarge the scope of their antifungal efficacy against Cephalosporium maydis in vitro and in vivo studies.

\section{Materials and Methods}

Silver nanoparticles biosynthesis

AgNPs were produced by Aspergillus niger according to Rabie et al. (2013) method.

\section{Characterization of silver nanoparticles}

The developed AgNPs were assessed by UV-Vis analysis using JASCO-V630 Spectrophotometer at $\lambda 200-600 \mathrm{~nm}$, normalizing to controls. The size of the developed AgNPs was determined using Zeta seizer Nano S (ZEN 1600, Malvern, UK). Transmission Electron Microscopy TEM assessed the morphology and size of AgNPs (FP 5018/40, Technol G2 Spirit Bio TWIN) according to Ahmad et al. (2003). Fourier Transform Infrared Spectroscopy (FTIR) (Thermo Nicolet model 6700 spectrum) detected the presence of functional groups of amino acids as protecting agents to AgNPs. The charge of silver nanoparticles was determined by Zeta potential analysis (ZEN 1600, Malvern, UK) Dispersion Software. (Nano ZS) Malvern, UK. Zeta potential rang $(\mathrm{mV})$ : $\mathrm{mV}$, (Kheybari et al., 2010). Sterile distilled water with silver nitrate was used as negative control. Reducing agent assay (Protein Content) is calorimetrically measured Bradford assay method, then protein concentration measured spectrophotometrically at 595nm (Bradford, 1976).

\section{Optimization of nanoparticle biosynthesis}

The $\mathrm{pH}$ of this reaction was optimized by using different $\mathrm{pH}$, where the reaction $\mathrm{pH}$ was maintained at 2, 5, 7, 9 and 11. The $\mathrm{pH}$ was adjusted by using $0.1 \mathrm{~N} \mathrm{HCl}$ and $0.1 \mathrm{~N} \mathrm{NaOH}$. The temperature of this reaction was optimized by using different temperature degrees, where the reaction temperature was monitored at $\left(15 \mathrm{C}^{\circ}, 25 \mathrm{C}^{\circ}, 30 \mathrm{C}^{\circ}, 35^{0}, 40 \mathrm{C}^{0}, 45 \mathrm{C}^{0}\right.$ and $\left.50^{\circ} \mathrm{C}\right)$. The concentration of silver nitrate was optimized using different concentrations, where the electron donor in the process of nanoparticle synthesis and bioreduction of silver nitrate $\left(\mathrm{AgNO}_{3}\right)$, Yeast extract, $\mathrm{NaNo}_{3}, \mathrm{NH}_{4} \mathrm{SO}_{4}$, and Methionine (as the electron donor- Nitrogen source) was added to the reaction mixture. The absorbance of the resulting solutions was measured spectrophotometrically.

\section{Stability study}

Biosynthesis of AgNPs in every optimized condition was kept in dark at the room temperature and the stability of the synthesized particles was monitored up to 60 days by using UV-visible spectral analysis.

\section{In vitro screening of tested AgNPs and fungicides against}

Pathogenic fungus (C. maydis)

In vitro assay was performed on Potato dextrose agar (Bilgrami \& Verma, 1981) either alone or combined with each one of Maxim XL or Vitavax at the rate of $2 \mathrm{~g} \backslash \mathrm{L}$ (after preliminary trails and unpublished data) were poured into growth media prior to pouring in a Petri dish $(9 \mathrm{~cm}$ in diameter). Three replicates were used for each concentration. Five $\mathrm{mm}$ in diameter agar plugs were obtained from the actively growing C.maydis (7 old day cultures) inoculated in the center of plates supplemented with different treatments. The plates were incubated at $28^{\circ} \mathrm{C}$ for 9 days. Colony diameters were measured every $72 \mathrm{~h}$ until full growth in control. Control plates inoculated by $C$. maydis in growth medium without neither AgNPs nor fungicides. The percentage of inhibition zones were measured compared with control using the following formula:

$$
\text { Inhibition rate }(\%)=(\mathrm{R}-\mathrm{r}) / \mathrm{R} \times 100
$$

where $\mathrm{R}$ is radial growth of fungi in control and $r$ is the radial growth of fungi in treated plates.

Effect of AgNPs and fungicides on the mycelial weight of pathogen

Potato dextrose broth (PDB) was dispensed into $250 \mathrm{ml}$ conical flasks at the rate of $100 \mathrm{ml}$ per flask and were sterilized by autoclaving at $121^{\circ} \mathrm{C}$ for $20 \mathrm{~min}$. Five $\mathrm{ml} / \mathrm{L}$ of $50 \mathrm{ppm} \mathrm{AgNPs}$ either alone or combined with each of Maxim XL or Vitavax at the rate of $2 \mathrm{~g} \backslash \mathrm{L}$ (after preliminary trails and unpublished data) were poured into growth media. The media were allowed to cool down $\left(30^{\circ} \mathrm{C}-40^{\circ} \mathrm{C}\right)$ before chloramphenicol (1\%) was added aseptically to suppress 
bacterial growth. The fungal isolate of C.maydis introduced directly from the inoculated plates. The flasks were incubated at $30^{\circ} \mathrm{C}$ for seven days then the mycelial weights were recorded.

$$
\text { Inhibition rate }(\%)=(\mathrm{R}-\mathrm{r}) / \mathrm{R} \times 100
$$

where $\mathrm{R}$ is the dry weight of fungi in control and $\mathrm{r}$ is the dry weight of fungi in treated flasks.

Effect of tested AgNPs and fungicides against C.maydis under greenhouse conditions

Effect of tested AgNPs: The greenhouse experiment was carried out to study the virulence of AgNPs biosynthesis by A. niger. An aggressive isolate of C.maydis was grown in bottles containing $50 \mathrm{~g}$ sorghum grains/each. Five $\mathrm{ml} /$ pot of 100ppm AgNPs either alone or combined with each of Maxim XL or Vitavax at the rate of $2 \mathrm{~g} \backslash \mathrm{L}$ were added on each bottle. Sterilized Nile silt soil was infested by isolate at the rate of $50 \mathrm{~g}$ of fungal material per pot of $2 \mathrm{~cm}$ in diameter. Maize grains were surface sterilized. Four pots were cultivated with maize grains of susceptible cultivar (Baladi) (Hassanein et al., 2002) and then prepared as five plants per pot for each cultivar. Plants were fertilized at the rate of $3 \mathrm{~g}$ urea $(46 \% \mathrm{~N})$ per pot and regularly watered using tap water (Zeller et al., 2002). The temperature was ranged between $25^{\circ} \mathrm{C}$ and $30^{\circ} \mathrm{C}$. Disease readings were recorded after 90 days of cultivation as the percentage of wilted plants. The lower internodes and the top internodes were injected with $2 \mathrm{ml}$ of $30 \mathrm{ppm}$ AgNPs for each plant. Injections were performed using $10 \mathrm{ml}$ sterile plastic syringes with 25 or 26 gauge needle (Skibbe \& Walbot, 2010). In the first maize plants were injected after 7 days of cultivation. Beyond this period the injection was conjugated every 15 days until 60 days of sowing. Five replicates of control plants without injection with either AgNPs or fungicides were used.

Fungicides applications: Four pots $25 \mathrm{~cm}$ diameter were infested with $C$. maydis then cultivated with susceptible maize varieties (Baladi) indicated high degree of infestation. Fungicides was used Maxim XL (Fludioxonil $2.5 \%+$ Metalaxyl $1 \%$ ) at the rate of $3 \mathrm{ml} \backslash \mathrm{L}$, as well as, Vitavax (5, 6-Dihydro-2-methyl-1-14-oxathiin-3-carboxanilide) at the rate of $3 \mathrm{~g} \backslash \mathrm{L}$. Seeds were treated with the fungicide before cultivation. Infected plants were counted after 90 days from cultivation (Ibrahim et al., 1993).

\section{Results \& Discussion}

Characterization of AgNPs produced by A. niger.

$A$. niger has the potentiality to reduce $\mathrm{Ag}^{+}$ to $\mathrm{Ag}^{0}$ as revealed from the UV-Vis, TEM and DLS analyses, In addition, $A$. niger undergone to biochemical identity for optimized metabolites implicated with a synthesis of AgNPs as summarized in Fig. 1. The occurrence of yellow to brownish color suggesting the consistency of AgNPs, besides lack of precipitations or agglomeration assure the homogeneity and stability of developed AgNPs (Fig. 1A). There are differences in Ag-NPs production before and after optimization. At visual observation, it was observed that there are increasing in the degree of color of AgNPs after optimization compared with before optimization. Thus, the increasing of color sharpness happened in respect of progressively mounting AgNPs concentration formed through conversion of silver ions that obtainable in the hydrous medium. Fungal extract without $\mathrm{AgNO}_{3}$ and sterile distilled water with $\mathrm{AgNO}_{3}$ as control had no variation in the medium appearance under same conditions as reported with Jain et al. (2011) and Zhang et al. (2011). From the UV-Vis analysis, the Maximum absorption of the developed AgNPs by $A$. niger was centered at 420, 430nm (Fig. 1B). In addition, the absorbance of Ag-NPs that formed at wavelength $(420 \mathrm{~nm})$ increased after optimization that revealed at 1.25OD compared with those before optimization $0.8 \mathrm{OD}$ (Fig. 1B). Sharpness mounting of medium appearance because of the nanoparticles consisted in the aqueous solution in accordance with Saeed et al. (2012).

The average hydrodynamic diameter and polydispersity indexes of the developed AgNPs for the experimented fungus were evaluated by DLS analysis (Fig. 1C). The size of Nanoparticles was decreased after optimization at $(9 \mathrm{~nm})$ compared with before optimization at $(19 \mathrm{~nm})$. In addition, the appearance of sole top specified the goodness of AgNPs biosynthesized with the highest homogeneity similar with Maria (2011) and Shameli et al. (2012). The size and shape of the synthesized AgNPs by the experimented fungi were determined from the TEM analysis (Fig. 1D). AgNPs had variable shapes that depending on the identity of reducing agents and stabilizing compounds from each species, however, most of the fungal synthesized AgNPs had spherical and triangular shapes. AgNPs diameter of A. niger 
ranged from 6-13nm. TEM was showed clear and obvious nanoparticles after optimization compared with before optimization. This similar

\section{Before optimization}

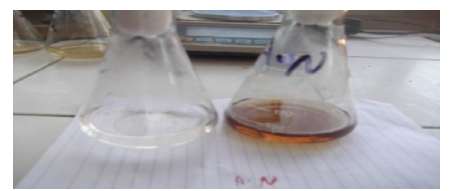

A-

B-

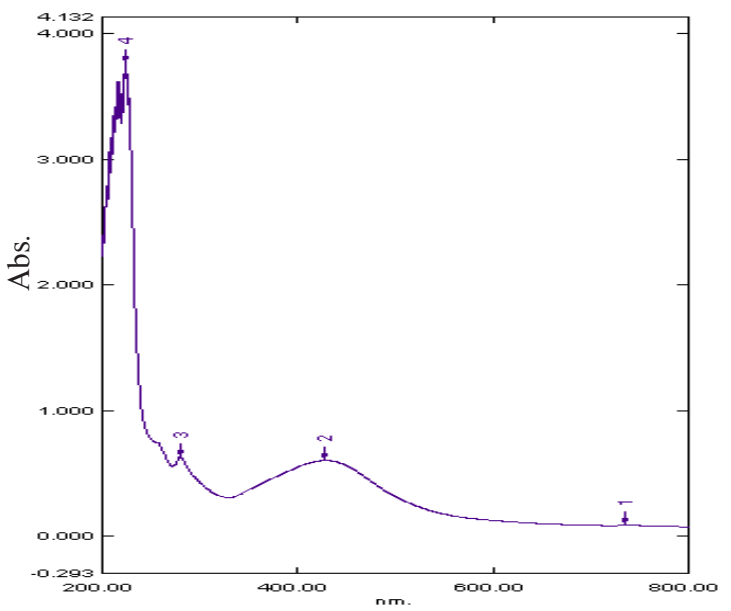

Size Distribution by Number

C-

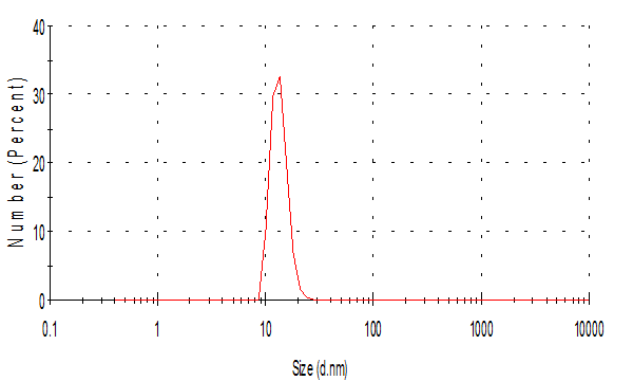

D-

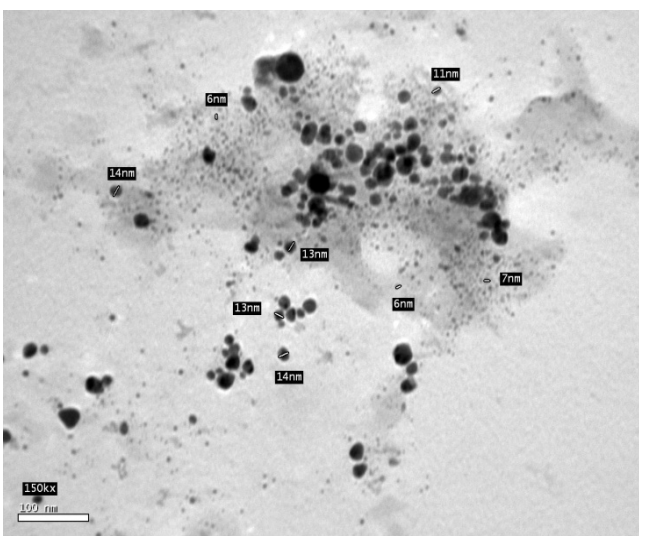

to that reported by Balaji et al. (2009) and Kasthuri et al. (2009).

\section{After optimization}
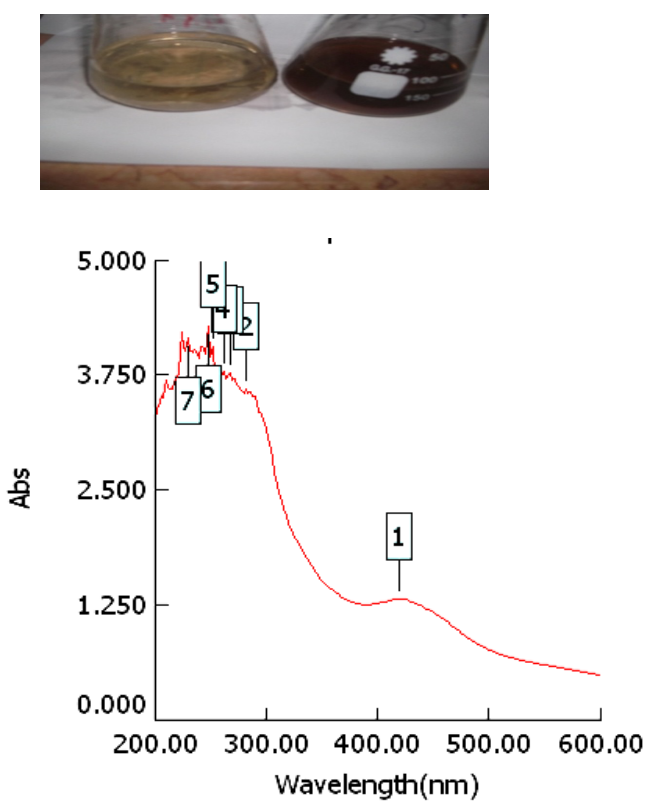

Size Distribution by Number

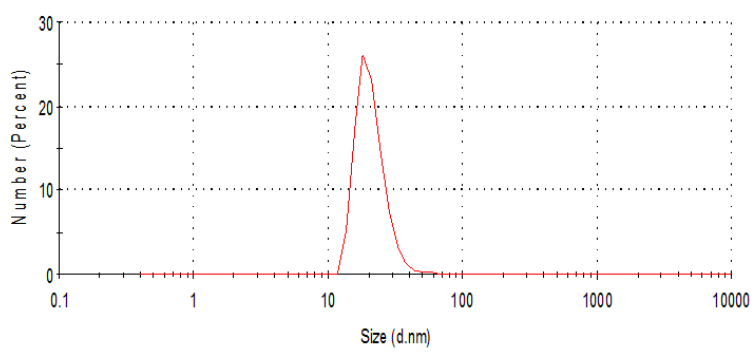

Fig. 1. Biosynthesis of silver nanoparticles by the tested Aspergillus niger (A)-Visual observation, left (control without $\mathrm{AgNo}_{3}$ ), Right (with $\mathrm{AgNo}_{3}$ ); (B)-UV-Vis analysis; (C)- Size analysis and (D) -TEM. 
The colloidal stability of AgNPs synthesized by $A$. niger extracts is consistent with those reported for other fungi (Absar et al., 2003) and Azospirillum (DeSanti et al., 2010). To further validate the presence of stabilizing proteins, $A$. niger extracts were analyzed by FTIR, confirming the presence of various functional groups at $1643.2 \mathrm{~cm}^{-1}, 1604.7 \mathrm{~cm}^{-1}, 1801.4 \mathrm{~cm}^{-1}, 3994.5 \mathrm{~cm}^{-1}$ and $3201.6 \mathrm{~cm}^{-1}$ corresponding to carbonyl residues and peptide bonds of proteins (Fig. 2). The band at $1801.4 \mathrm{~cm}^{-1}$ referred to $\mathrm{C}=\mathrm{C}$ alkenyl group stretch of protein in solution, whereas the bands at $1643.2 \mathrm{~cm}^{-1}$ and $1604.7 \mathrm{~cm}^{-1}$ are belonging to the amide I and II bonds. Similar results showing the presence of aldehyde and keto groups as stabilizing and capping agents to AgNPs synthesized from fungi (Duran et al., 2005 and Moteshafi et al., 2012). The bands at $1643.2 \mathrm{~cm}^{-1}$ are belongs to carbonyl stretch of unsaturated aldehyde, ketone and alkene group, while the bands at $1604.7 \mathrm{~cm}^{-1}$ are belongs to the $\mathrm{NH} 2$ extent.
The absorption peak at $260-280 \mathrm{~nm}$ on the fungal extracts reveals the presence of proteins or aromatic amino acids that involved in the reduction of $\mathrm{Ag}+$, stabilizing these particles. This is consistent with that reported with Welinder (1979). Reducing Agent Assay of protein concentration was detected in the filtrates of $A$. niger $(3.133 \pm 0.371 \mathrm{mg})$. From the obtained data, $A$. niger represented as frequent genus displaying actually potency for protein production. The strong fungal AgNPs productivity had been attributed to secretion of abundant extracellular redox proteins, diverse metal reductases, thus reducing soluble metal ions into their insoluble nanocrystals (Gericke \& Pinches, 2006). From our results, the presence of the peaks of amino acids in UV-Vis- Spectra support the presence of proteins similarly with Duran et al. (2005) and Balaji et al. (2009).

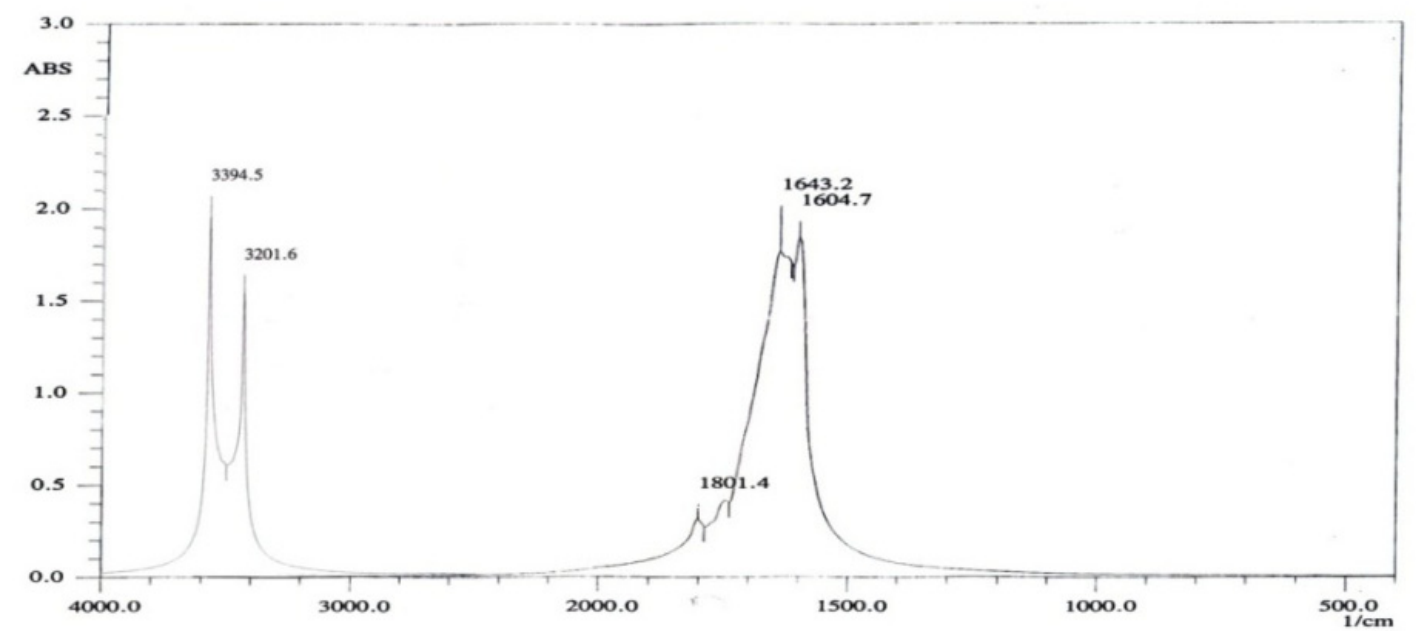

Fig. 2. FTIR measurements for siver nanoparticles biosynthesis by produced $A$. niger.

To assess the degree of stability of synthesized AgNPs, the charge was measured by Zeta potential. Zeta potential of AgNPs from A. niger was $(29.3 \mathrm{mv})$ after optimization that is suggested the higher stability of this NPs compared with before optimization $(-26.4 \mathrm{mV})$ with one low peak (Fig. 3A and B). Also, the higher negative charge of AgNPs from our results as measured by zeta potential confirm the repulsion of the synthesized particles subsequently led to stability and monodispersity of the synthesized AgNPs solution, this in accordance with Gericke \& Pinches (2006), Shaligram et al. (2009) and Moteshafi et al. (2012).

\section{Optimization of AgNPs production Effect of $p H$ on AgNPs biosynthesis}

From our results, Fig. 4A shown that the optical photograph of the color change in the bulk material $\left(\mathrm{AgNO}_{3}\right)$, that were adjusted at different $\mathrm{pH}$, from colorless in to yellow, after $24 \mathrm{~h}$ of incubation with $A$. niger extract at room temperature. The appearance of a yellow color is a clear indication for bioreduction of $\mathrm{Ag}^{+}$into AgNPs. At $\mathrm{pH} 5, \mathrm{AgNO}_{3}$ remains colorless. While at $\mathrm{pH}$ more than 5 , a yellow color with different densities appeared after $24 \mathrm{~h}$ of incubation with fungal extract. While at pH 6 and more, AgNPs was biosynthesized and density of colored 
solution increased. In addition, Ag-NPs were biosynthesized at all $\mathrm{pH}$ that ranged from 7, 8 and 9 that recorded absorbance peaks in visible region (480nm) (Fig. 4B). So, it was observed from our results that $A$. niger has the ability for nanosilver production with higher yield that increased gradually by increasing in $\mathrm{pH}$ range 7,8 and 9 , respectively. On other hand, $\mathrm{pH} 6$ recorded low production of AgNPs by A. niger. In addition, the

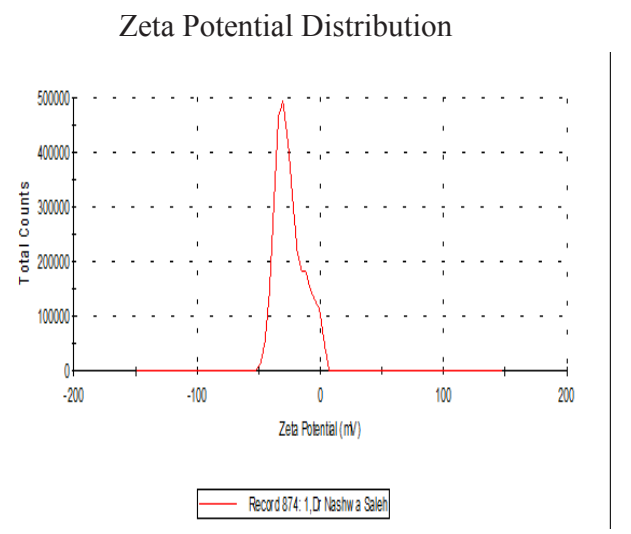

A-Before optimization (-26.6) least broaden spectrum is represented when the bioreduction process proceeds at $\mathrm{pH} 9$ were the Maximum absorption is $495 \mathrm{~nm}$. While, A. niger does not has the ability for AgNPs production at $\mathrm{pH}$ 5. Thus, $A$. niger has the ability for higher yield of AgNPs production at alkaline $\mathrm{pH}$ than those $\mathrm{pH}$ treatments that recorded lower yield of AgNPs production. Similar results also reported by Kasthuri et al. (2009).

Zeta Potential Distribution

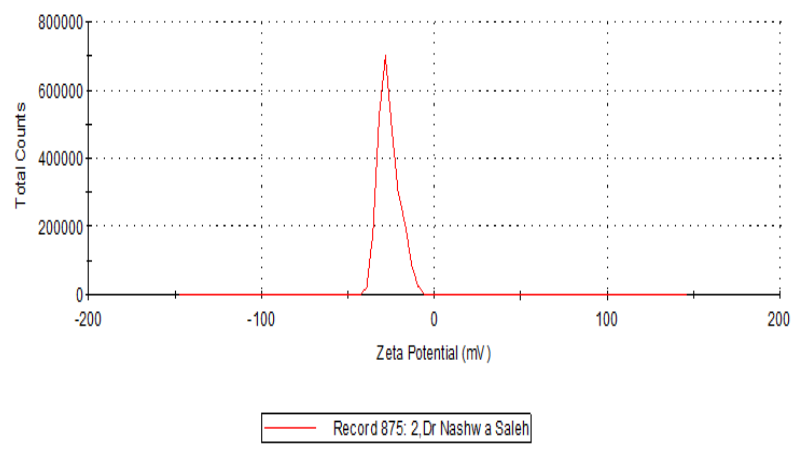

B-After optimization(-29.3)

Fig. 3. Zeta potential for negative charge of siver nanoparticles of A.niger .

A-

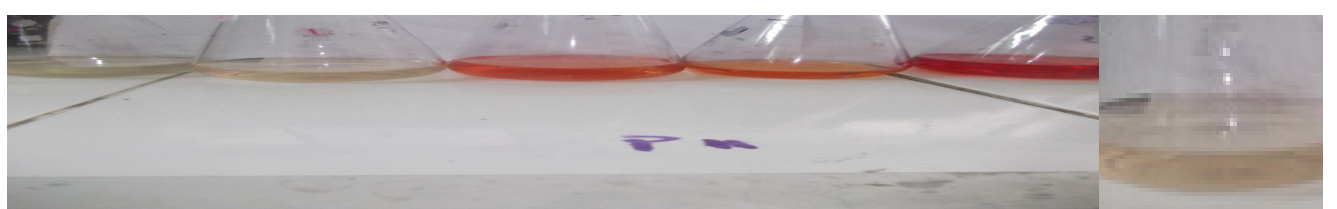

b

d

e

f
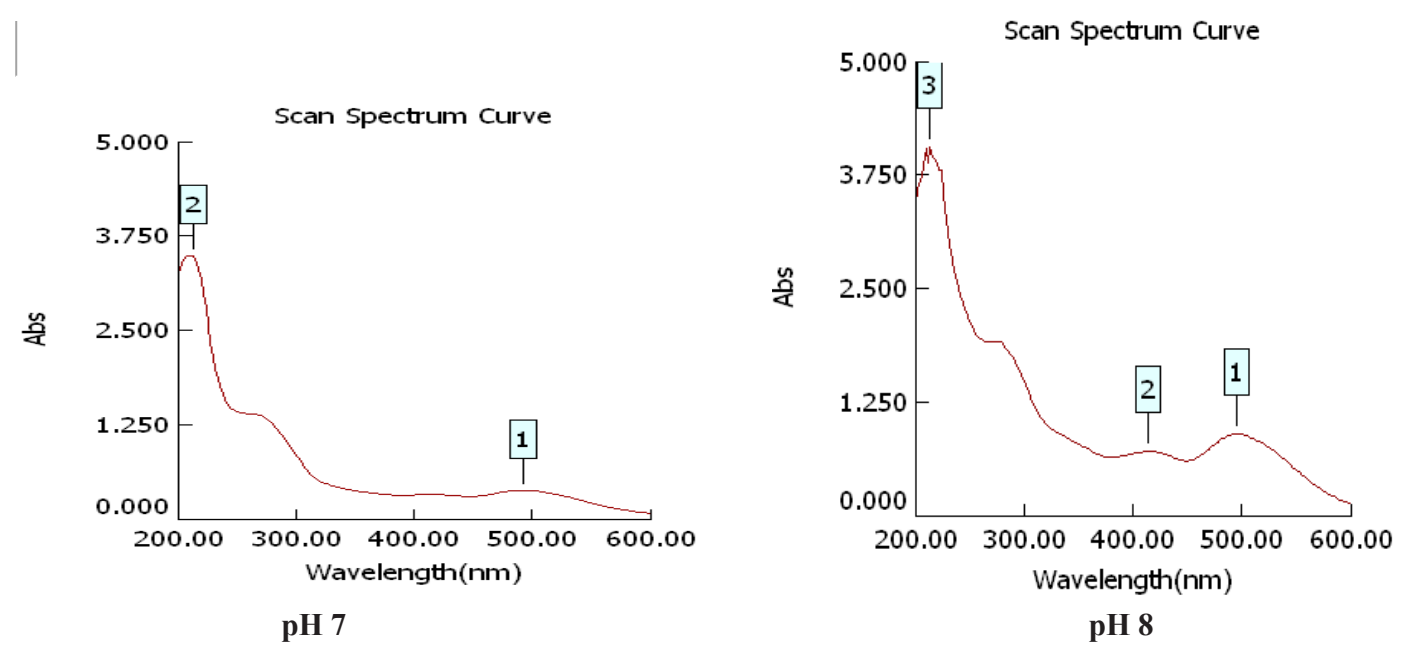

Fig. 4. Different range of pH: (a) pH 5, (b) pH 6, (c) pH 7, (d) pH 8, (e) pH (9) and (f) pH 10 affect on production of nano silver particles produced by Asperigillus niger. A- Visual observation, B-UV-visible . 
Effect of temperature on AgNPs biosynthesis

It was observed from our results that $A$. niger has the ability for AgNPs production with higher yield that recorded at $30^{\circ} \mathrm{C}$ as shown in Fig. $5 \mathrm{~A}$. On other hand, $A$. niger do not has the ability for AgNPs production at lower temperature as $15^{\circ}$ and $20^{\circ} \mathrm{C}$ or higher temperature as $40^{\circ}$ and $50^{\circ} \mathrm{C}$. Thus, temperature at $30^{\circ} \mathrm{C}$ recorded the best optimized temperature for higher yield of AgNPs production by $A$. niger compared with the other tested ranges of temperature, (Fig. 5B). That is revealed by Welinder (1979) and Shaligram et al. (2009).

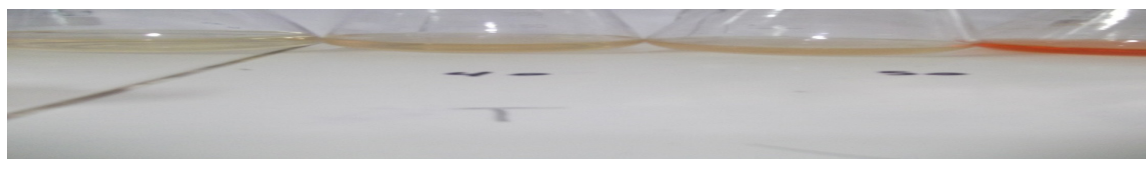

A-

a

b

c

d

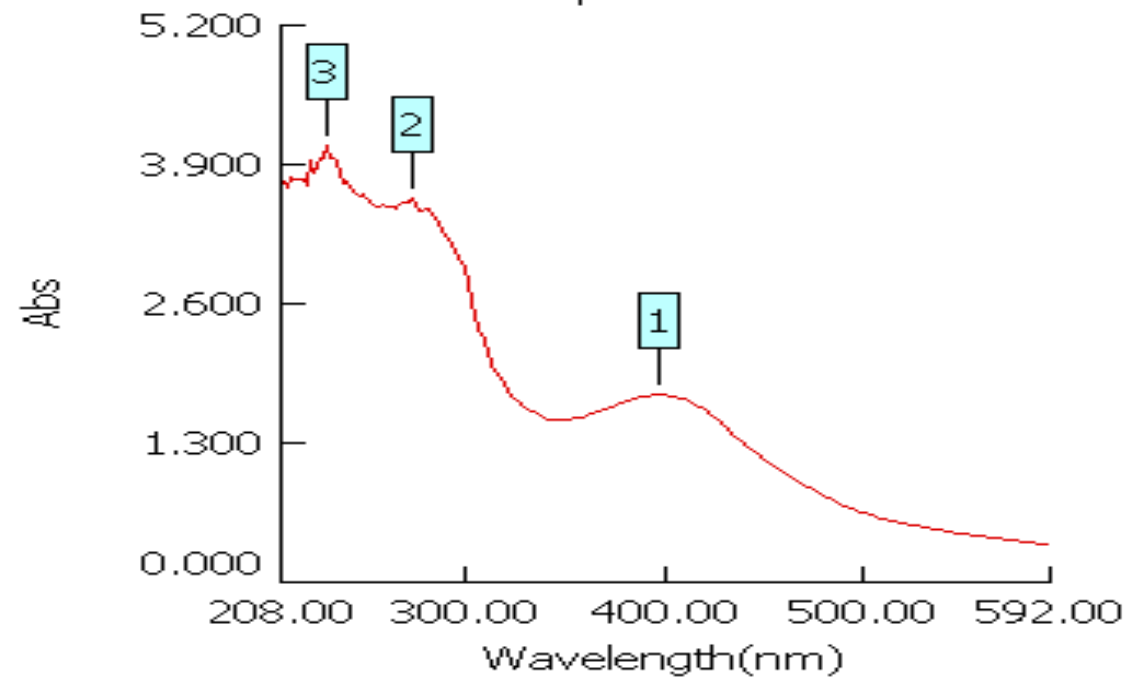

Fig. 5. Effect of temperature on production of nano silver; (A) Visual observation: Effect of different ranges of temperature on production of nano silver $\left(\mathrm{a}: \mathbf{1 5}^{\circ}, \mathrm{b}: \mathbf{4 0 ^ { \circ }}, \mathrm{c}: 50^{\circ}\right.$ and $\left.\mathrm{d}: 30^{\circ} \mathrm{C}\right)$; (B) $\mathrm{UV}$ - Visible of nano silver at temperature effect at $30^{\circ} \mathrm{C}$.

Effect of silver nitrate concentration

By gradual increasing in concentration of $\mathrm{AgNO}_{3}$ from $0.1,0.2,0.5,1$ to $2 \mathrm{mM}$ was accompanied with increasing in nanoparticle production (Fig. 6), respectively. However, the gradual increasing of $\mathrm{AgNo}_{3}$ concentration more than $2 \mathrm{mM}$ as $3 \mathrm{mM}$ gave decreasing concentrations in nanosilver biosynthesis. That is revealed by Maggy et al. (2007), Balaji et al. (2009), Varshney et al. (2009) and Veerasamy et al. (2011).

\section{Effect of electron donor}

From the results (Fig. 7), the reduction reaction started quickly was observed in the presence of glucose $5 \mathrm{mM}$. In addition, it was observed that the importance of glucose as electron donor and it's positive effect on nanoparticle production compared with the presence of other electron donors as lactose, fructose, mannitol, and xylose. (Fig. 7A and $\mathrm{C}$ ). In addition, nitrogen source as Yeast extract, $\mathrm{NaNo}_{3}$ and $\mathrm{NH}_{4} \mathrm{So}_{4}$ have positive effect on the reduction reaction (Fig. 7B and D) as proved by Krishnaraj et al. (2012).

The biochemical identity of optimized A. niger metabolites implicated with a synthesis of AgNPs

Our results showed that the optimization process of $A$. niger metabolites plays a pivotal role in the nanoparticles stability and aggregation. Moreover, the increase in the absorbance of AgNPs produced by A.niger after its optimization compared with those before optimization. These results came in accordance to those reported previously by Korbekandia et al. (2013).

Antifungal efficacy of AgNPs against C. maydis

The obtained results (Table 1 and Plate 1) revealed that AgNPs activity against the phytopathogen $C$. maydis either alone or in combination with each of chemical fungicides Maxim Xl and Vitavax. The results of single treatments indicated that the higher rate of inhibition of C.maydis can be achieved in presence of AgNPs accounting for $51 \%$ of fungal growth. 
In addition, AgNPs were also very effective more than synthetic fungicides. Kim et al. (2012), Sang -Woo et al. (2012) and Hien et al. (2015) found that in vitro assays indicated that AgNPs had an effect on phytopathogen. Results presented in Table 1, revealed Maximum inhibitions of mycelial dry weight of $C$. maydis were recorded as $55 \%$ in the presence of AgNPs compared the two fungicides. In addition, the results also revealed that the presence of AgNPs increased the efficacy of Maxim XL and Vitavax accounting for $64.7 \%$ and $94.8 \%$, respectively.

In previous studies, AgNPs disrupt transport systems, including ion efflux (Morones et al., 2005; Khadri et al., 2013 and Qazi \& Javaid 2016). Our results also presented in Table 1 clearly showed the presence of AgNPs increase the antifungal activities of chemical fungicides from $36 \%$ and $30 \%$ to $81 \%$ and $64 \%$ in case of
Vitavax and Maxim XL, respectively. Indeed there are several supporting reults that AgNPs has phytopathogenic activity (Potara et al., 2011; ElRafie et al., 2014 and Calagua et al., 2015).

The results illustrated in Table 2 indicated that, all different treatments of AgNPs, Maxim $\mathrm{XL}$, and Vitavax had different influences on decreasing the percentage of infection with late wilt disease caused by C.maydis compared to control. The higher efficiency of treatments recorded in the presence of AgNPs either alone $(57.7 \%)$ or combined with Maxim XL $(75.5 \%)$ or Vitavax $(90 \%)$ as proved by Kanto et al. (2005) and Chitturi et al.(2016). Sharma et al. (2012) proved that the inhibitory effects of AgNPs on Sphaerotheca pannosa Var rosae. It can be concluded that the bio-AgNPs had evaluated against phytopathogens (Lamsa et al., 2011; Patel et al., 2014 and Ahmed et al., 2017).

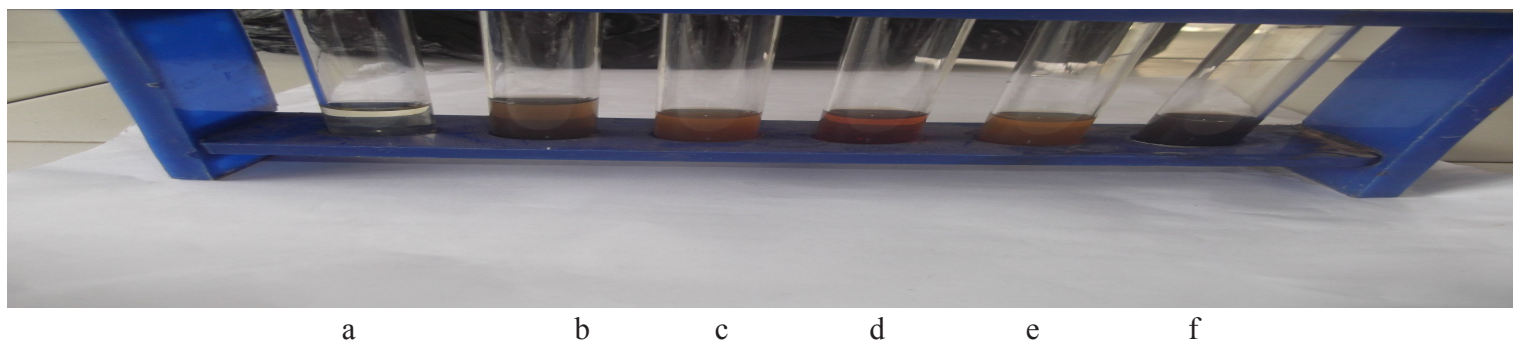

Fig. 6. Effect of different concentration of silver nitrate on production of nanosilver particales at: (a) Without any metals, (b) $0.1 \mathrm{mM}$, (c) $0.2 \mathrm{mM}$, (d) $0.5 \mathrm{mM}$, (e) $1 \mathrm{mM}$, and (f) $2 \mathrm{mM}$.
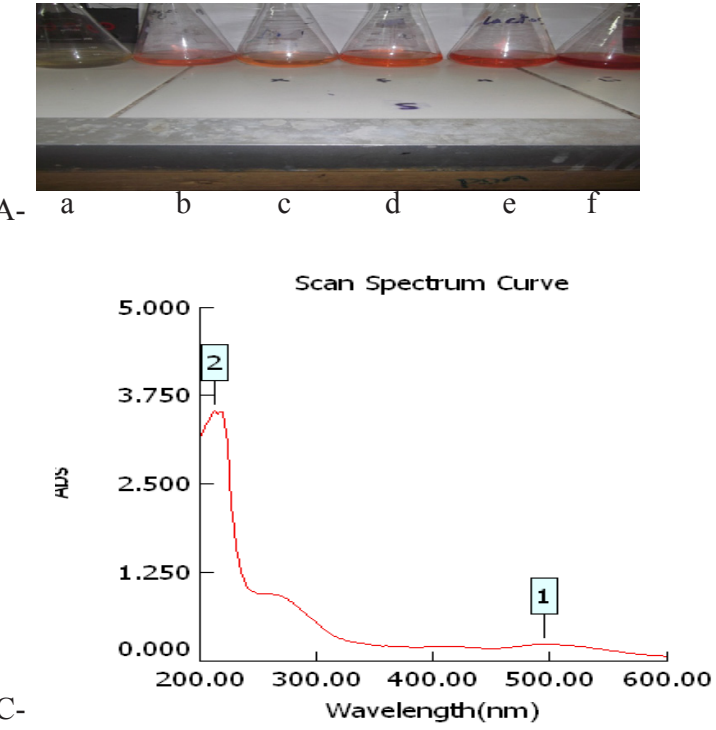

B-

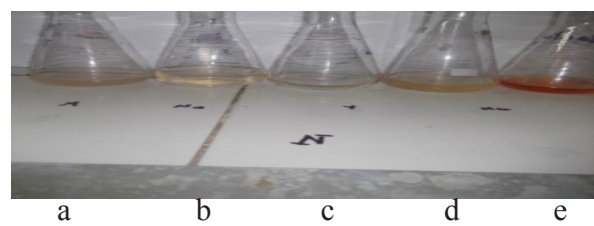

D-

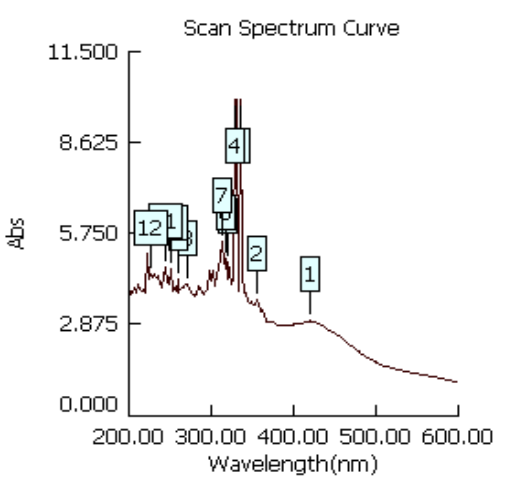

Fig. 7. Effect of different electron donor concentration of carbon and nitrogen sources on production of nano silver particles. (A) Visual observation of silver nanoparticles with carbon sources, a- Control (without carbon source), b- Fructose, c- Maltose, d- lactose, e- xylose, f- glucose. (B) Visual observation in the presence of nitrogen sources, a- Methionine, b- Amonium sulphate, c- Yeast extract, d- Sodim nitrate, eAmonium sulphate and yeast extract. (C) UV-visible of nano silver particles with Glucose. (D) UV-visible spectrophotometer of silver nano with mixture of ammonium sulphate and yeast extract. 
TABLE 1. Effect of Maxim XL and Vitavax alone and in combination with silver nanoparticles on the dry weight and pathogenicity of $C$. maydis.

\begin{tabular}{lcccc}
\hline Treatment & Diameter growth $(\mathbf{c m})$ & $\begin{array}{c}\text { Inhibition } \\
\text { rate\% }\end{array}$ & Dry weight & $\begin{array}{c}\text { Inhibition } \\
\text { rate\% }\end{array}$ \\
\hline Control & 7.6 & - & 0.176 & 55 \\
Nanosilver 5ml/L of 50ppm & 3.7 & 51 & 0,079 & 50.5 \\
Vitavax 2g\L & 4.8 & 36 & 0.087 & 43.7 \\
Maxim XL 2g\L & 5.3 & 30 & 0.134 & 64.7 \\
Nano + Maxim XL & 2.7 & 64 & 0.081 & 94.8 \\
Nano + Vitavax & 1.4 & 81 & 0.099 & \\
\hline
\end{tabular}
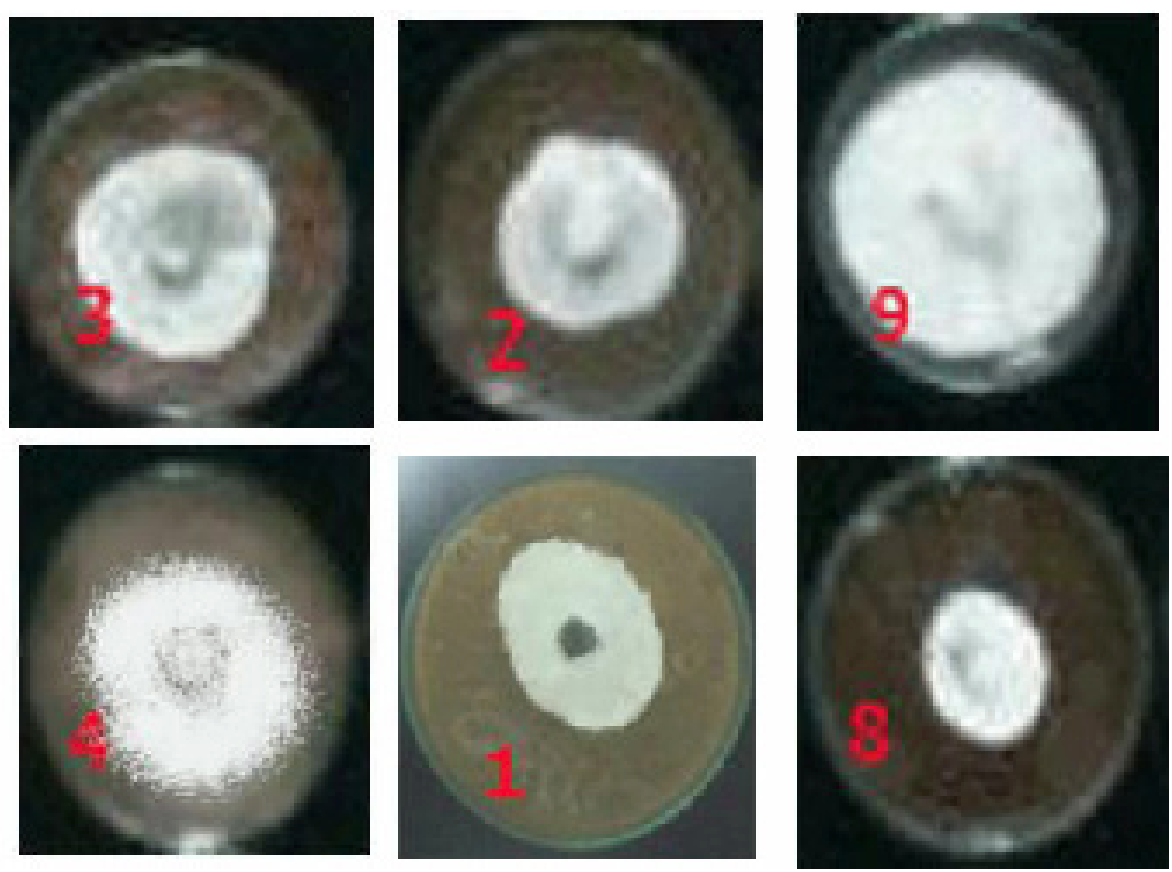

Plate 1. Rate of $C$. maydis growth in the presence of Maxim XL $2 \mathrm{~g} \backslash$ lit and Vitavax $2 \mathrm{~g} \backslash \mathrm{lit}$ alone and in combination with silver nanoparticles $5 \mathrm{ml} / \mathrm{L}$ of $50 \mathrm{ppm}$. (9) Control $C$. maydis, (2) $C$. maydis with silver nanoparticles, (3) C. maydis with Vetavax, (4) C. maydis with Maxim XL, (1) $C$. maydis with Nano + Maxim XL and (8) $C$. maydis with Nano + Vitavax.

TABLE 2. Effect of Maxim XL and Vitavax alone and in combination with silver nanoparticles on the pathogenicity of $C$. maydis after 90 days of incubation of treatments as source of inoculums to maize plants.

\begin{tabular}{lcc}
\hline Treatments & Mean of infection\% & Efficiency of treatments\% \\
\hline Control & 90 & 57.7 \\
Nano silver $5 \mathrm{ml} / \mathrm{L}$ of $50 \mathrm{ppm}$ & 38 & 48.8 \\
Maxim $2 \mathrm{~g} \backslash \mathrm{L}$ & 46 & 54 \\
Vetavax $2 \mathrm{~g} \backslash \mathrm{L}$ & 41 & 75.5 \\
Nano + Maxim XL & 22 & 90 \\
Nano + Vitavax & 13 & \\
\hline
\end{tabular}

Efficiency $\%=[\mathrm{C}-\mathrm{T} \backslash \mathrm{C}] \mathrm{x} 100 \quad \mathrm{~T}$ : Treatment $\quad$ C: Control




\section{Conclusion}

Finally, we concluded that the efficiency of AgNPs in reducing the incidence of late wilt disease in maize was higher than those of the fungicide used. In addition, the antifungal activity of all treatments showed similar trends in both vitro and vivo studies. These results suggested the possibility of using AgNPs to eradicate phytopathogens. Moreover, with the evaluation of AgNPs against phytopathogens, further experiments are required for presentation several explanations about the action mechanism of AgNPs with pathogen cell and getting a better understanding of the antifungal efficiency of AgNPs.

\section{References:}

Absar A, Priyabrata, M., Satyajyoti, S., Deendayal, M., Khan, I. et al. (2003). Extracellular biosynthesis of silver nanoparticles using the fungus Fusarium oxysporum. Colloids and Surfaces. B: Biointerfaces, 28, 313-318.

Ahmad, A., Mukherjee, P., Senapati, S., Mandal, D., Khan, M.I., Kumar, R. and Sastry, M. (2003) Extracellular biosynthesis of silver nanoparticles using the fungus Fusarium oxysporum. Colloids Surf. B: Biointerface, 28, 313-318.

Ahmed, A.I.S. (2017) Chitosan and silver nanoparticles as control agents of some faba bean spot diseases. $J$. Plant Pathol. Microbiol. 8, 421-28.

Al-Askar, A.A., Hafez, E.E., Kabeil, S.A. and Meghad, A. (2013) Bioproduction of silver-nano particles by Fusarium oxysporum and their antimicrobial activity against some plant pathogenic bacteria and fungi. Life Science Journal, 10(3), 2470-2475.

Balaji, D.S., Basavaraja, S., Deshpande, R., Mahesh, D.B., Prabhakar, B.K. and Venkataraman, A. (2009) Extracellular biosynthesis of functionalized silver nanoparticles by strains of Cladosporium cladosporioides fungus. Colloids and Surfaces. B: Biointerfaces, 68(1), 88-92.

Bilgrami, K.S. and Verma, R.N. (1981) "Physiological of Fungi". $2^{\text {nd }}$ ed., pp. 23-27. Vikas Publishing PTV., LTd Indian.

Bradford, M.M. (1976) A rapid and sensitive method for the quantification of microgram quantities of protein utilizing the principle of protein-dye binding. Anal. Biochem. 72, 248-254.

Calagua, A., Alarcon, H., Paraguay, F. and Rodriguez, J. (2015) Synthesis and characterization of bimetallic gold-silver core-shell nanoparticles: A green approach advances in nanoparticles, 4, 116121.

Chitturi, L.K., Yaramma, A., Merugu, R., Dachepalli, R. and Kandhadi, J. (2016) Synthesis and characterization of In2O3 nanoparticles from Astragalus gummifer. Advances in Nanoparticles, 5, 114-122.

DeSanti, M., Sisti, M., Barbieri, E., Piccoli, G. and Brandi, G. et al. (2010) A combined morphologic and molecular approach for characterizing fungal microflora from a traditional Italian cheese (Fossa cheese). International Dairy Journal, 20, 465-471.

Duran, N., Marcato, P.D., Alves, O.L., DeSouza, G.I.H. and Esposito, E. (2005) Mechanistic aspects of biosynthesis of silver nanoparticles by several Fusarium oxysporum strains. Journal of Nanobiotechnology, 3(8).

El-Rafie, M.H., Ahmed, H.B. and Zahran, M.K. (2014) Characterization of nanosilver coated cotton fabric and evaluation of its antibacterial efficacy. Carbohydrate Polymers, 107, 174-181.

Gericke, M. and Pinches, A. (2006) Biological synthesis of metal nanoparticles. Hydrometallurgy, 83, 132-140.

Hassanein, N.M., El-Ehalawy, A.A., Khater, H.M., El-Zahraa, A.K. and Youssef, A.Y. (2002) The potential of selected rhizosphere actinomycetes and yeast fungi for the biological control of late wilt disease of maize caused by Cephalosporium maydis. African J. Mycol. Biotech. 1, 167-188.

Hien, N.Q., Phu, D.V., Duy, N.N., Quoc, L.A., Lan, T.K., Quy, H.T., Van, H.T., Diem, N.H. and Hoa, T.T. (2015) Influence of chitosan binder on the adhesion of silver nanoparticles on cotton fabric and evaluation of antibacterial activity. Advances in Nanoparticles, 4, 98-106. http://dx.doi. org/10.1088/0957-4484/22/13/135101

Ibrahim, Thanaa F., Zein El-Abedeen, A., Dawood, Nadia A., El-Morsy, G.A. and El-Mersawy, E.M. (1993) Fungicidal and herbicidal application in 
relation to soil microflora and late - wilt disease of maize. Egypt. J. Appl. Sci. 8(4), 133-142.

Jain, N., Bhargava, A., Majumdar, S., Tarafdar, J.C. and Panwar, J. (2011) Extracellular biosynthesis and characterization of silver nanoparticles using Aspergillus flavus NJP08: A mechanism perspective. Nanoscale, 3(2), 635- 641.

Jha, A.K., Prasad, K., Prasad, K. and Kulkarni, A.R. (2009) Plant system: Nature's nanofactory. Colloids and Surfaces. B: Biointerfaces, 10, 12-18.

Kanto, T., Miyoshi, A., Ogawa, T., Maekawa, K. and Aino, M. (2004) Suppressive effect of potassium silicate on powdery mildew of strawberry in hydroponics. J. Gen. Plant Pathol. 70, 207-211.

Kasthuri, J., Veerapandian, S. and Rajendiran, N. (2009) Biological synthesis of silver and gold nanoparticles using apiin as reducing agent. Colloids and Surfaces. B. Biointerfaces, 68, 55-60.

Khadri, H., Alzohairy, M., Janard han, A., Kumar, A., and Narasimha, G. (2013) Green synthesis of silver nanoparticles with high fungicidal activity from olive seed extract. Advances in Nanoparticles, 2, 241-246.

Kheybari, S., Samadi, N., Hosseini, S.V., Fazeli, A. and Fazeli, M.R. (2010) Synthesis and antimicrobial effects of silver nanoparticles produced by chemical reduction method. Daru. 18(3), 168-172.

Kim, S.W., Jung, J.H., Lamsal, K., Kim, Y.S., Min, J.S. and Lee, Y.S. (2012) Antifungal effects of silver nanoparticles (AgNPs) against various plant pathogenic fungi. Mycobiology, 40(1), 53-58.

Korbekandia, H., Asharia, Z., Iravani, B.S. and Abbasi, C.S. (2013) Optimization of biological synthesis of silver nanoparticles using Fusarium oxysporum Iranian Journal of Pharmaceutical Research, 12 (3), 289-298.

Krishnaraj, C., Ramachandran, K., Mohan, R. and Kalaichelvan, P.T. (2012) Optimization for rapid synthesis of silver nanoparticles and its effect on phytopathogenic fungi. Spectrochimica Acta Part A, 93, 95-99.

Lamsa, K., Kim, S.W., Jung, J.H., Kim, Y.S., Kim, K.S. and Lee, Y.S. (2011) Inhibition effects of silver nanoparticles against powdery mildew on cucumber and pumpkin. Mycobiology, 39, 26-32.

Liu, Q., Chen, B., Wang, Q., Shi, X., Xiao, Z., Lin, J. and Fang, X. (2009) Carbon nanotubes as molecular transporters for walled plant cells. Nanolett. 9, $1007-$ 1010.

Maggy, F.L., Michael, E.F. and Gordon, S. (2007) Synthesis of palladium nanoparticles by reaction of filamentous cyanobacterial biomass with a palladium (II) chloride complex. Langmuir, 23, 8982-8987.

Maria, Z. (2011) Characteristics of silica nanopowders and sol containing immobilized nanoparticles of copper or silver. Polimery, 56(10), 765-768.

Morones, J.R., Elechiguerra, J.L., Camacho, A., Holt, K., Kouri, J.B., Ramirez, J.T. and Yacaman, M.J. (2005) The bactericidal effect of silver nanoparticles. Nanobiotechnology, 16, 2346-2353.

Moteshafi, H., Mousavi, S.M. and Shojaosadati, S.A. (2012) The possible mechanisms involved in nanoparticles biosynthesis. J. of Industrial and Engineering Chemistry, 18, 2046-2050.

Nair, R., Varghese, S.H., Nair, B.G., Maekawa, T., Yoshida, Y. and Sakthi Kumar, D. (2010) Nanoparticulate material delivery to plants. Plant Sci, 179, 154-163.

Panacek, A., Kolar, M., Vecerova, R., Prucek, R., Soukupova, J., Krystof, V., Hamal, P., Zboril, R. and Kvitek, L. (2009) Antifungal activity of silver nanoparticles against Candida spp. Biometals, 30, 6333-6340.

Patel, J.N., Desai, P., Patel, N. Jha and Gautam, H.G.K (2014) Agronanotechnology for plant fungal disease management: A Review. Int. J. Curr. Microbiol. App.Sci. 3(10), 71-84.

Potara, M., Jakab, E., Damert, A., Popescu, O., Canpean, V. and Astilean, S. (2011) Synergistic antimicrobial activity of chitosan-silver nanoparticles on Staphylococcus aureus. Nanotechnology, 22, Article ID: 135101. http://www.ncbi.nlm.nih.gov/ pubmed/21343644.

Qazi, U.K. and Javaid, R. (2016) A Review on metal nanostructures: Preparation methods and their potential applications. Advances in Nanoparticles, 5, 27-43. 
Rabie, G.H., Zein El-Abedeen, A. and Bakry, Amal A. (2013) Biological synthesis of silver nanoparticles using filamentous fungi. Nano Science and NanoTechnology, 7(5), 163-171.

Rabie, G.H., Hegazy, S.H., Shaban, Lamis D. and Raie, Diana S. (2014) Biosynthesis of nano-silver by cell- free secretions from seeds of Medicago sativa. American Journal of Life Sciences, 3(2), 1-4.

Reddy, K.A.G., Joy, M.J, Mitra, T., Shabnam, S. and Shilp, T (2012) Nanosilver - A Review. International Journal of Advanced Pharmaceutics, 2(1), 9-15.

Saeed, M., Behroz, M., Reza, A., Gharam, H. and Mehdi, Y. (2012) Biological synthesis of silver nanoparticles by Aspergillus flavus isolated from soil of Ahar copper mine. Indian J. of Science and Technology, 5(23).

Sang-Woo, K., Jin, H.J., Kabir, L., Yun, S.K., Ji, S.M. and Youn, S.L. (2012) Antifungal effect of silver nanoparticles (AgNps) against various plant pathogenic fungi. Mycobiology, 40(1), 53-58.

Sastry, M., Patil, V. and Sainkar, S.R. (1998) Electrostatically controlled diffusion of carboxylic acid derivatized silver colloidal particles in thermally evaporated fatty amine films. J. Phys. Chem. B, 102, 1404-1410.

Shaligram, N.S., Bule, M., Bhambure, R., Singhal, S.R., Sudheer Kumar -Singh, K.S., GeorgeSzakacs, G. and Pandey, A. (2009) Biosynthesis of silver nanoparticles using aqueous extract from the compactin producing fungal strain. Process Biochemistry, 44, 939-943.

Shameli, K., Ahmad, B.M., Emad, A., Al-Mulla, J., Azowa, N.I., Shabanzadeh, P., Rustaiyan, A., Abdollahi, Y., Samira, B., Sanaz, A., Sani, M. and Zidan, M. ( 2012 ) Green biosynthesis of silver nanoparticles using Callicarpa maingayi stem bark extraction. Molecules, 17, 8506-8517.

Sharma, K., Sharma, R., Shit, S. and Gupta, S. (2012) Nanotechnological application on diagnosis.
International Conference on Advances in Biological and Medical Sciences (ICABMS'2012) July 15-16, of a Plant Disease.

Singh, M., Singh, S., Prasad, S. and Gambhir, I.S. (2008) Nanotechnology in medicine and antibacterial effect of silver nanoparticles. Digest J. Nanomater Biostruct. 3, 115-122.

Skibbe, D.S. and Walbot, Virginia (2010) Maize host requirements for Ustilago maydis tumor induction. Sex Plant Reprod. 23, 1-13.

Solgi, M., Kafi, M., Taghavi, T.S. and Naderi, R. (2009) Essential oils and silver nanoparticles (SNP) as novel agents to extend vase-life of gerbera (Gerbera jamesonii cv. 'Dune') flowers. Postharvest Bio-Technol. 53, 155-158.

Varshney, R., Mishra, A.N., Bhadauria, S. and Gaur, M.S. (2009) A novel microbial route to synthesize silver nanoparticles using fungus Hormoconisresinae. Dig. J. Nanomater. Bios. 4, 349-355.

Veerasamy, R., Xin, T.Z., Gunasagaran, S., Xiang, T.F.W., Yang, E.F.C., Jeyakumar, N. and Dhanaraj, S.A. (2011) Saudi Chem. Soc. 15, 113-120.

Welinder, K.G. (1979) Amino acid sequence studies of horseradish peroxidase. European Journal of Biochemistry, 96, 495-502.

Zeller, K.A. , Ismael, A.M., EL-Assiuty, E.M., Fahmy, Zeinab M., Bekheet, Fawzia M. and John, Leslie F. (2002) Relative competitiveness and virulence of four colonial lineages of Cephalosporium maydis from Egypt toward greenhouse-grown maize. Plant-Disease, 86(4), 373-378.

Zhang, X., Yan, S., Tyagi, R. and Surampalli, R. (2011) Synthesis of nanoparticles by microorganisms and their application in enhancing microbiological reaction rates. Chemosphere, 82, 489-494.

(Received 5/4/2018; accepted 25/6/2018) 


\title{
تاثير جزيئات الفضة النانوية على فطر السيفالوسبوريوم مايديس في الفيفو والفيترو نشوي صالح الجزار و جمال حسن ربيع \\ قسم النبات و الميكروبيولوجي ـ كلية العلوم - جامعة الزقازيق ـ الزقازيق ـ مصر.
}

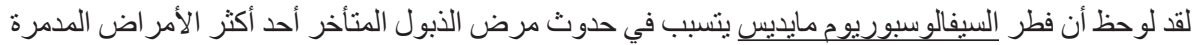

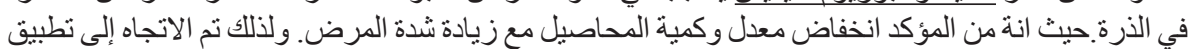

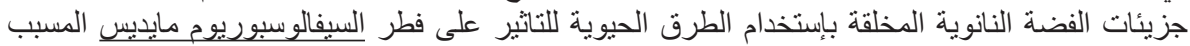

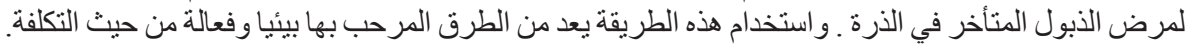

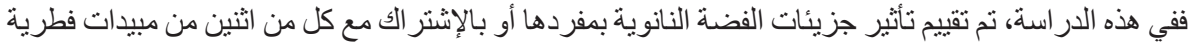

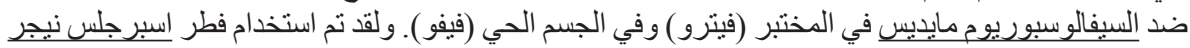

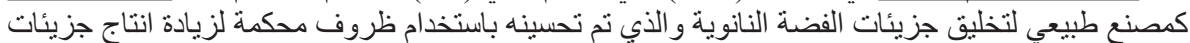

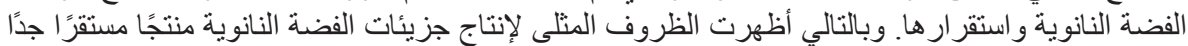

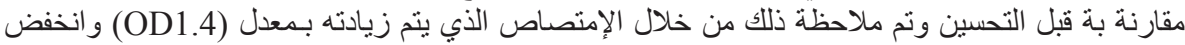

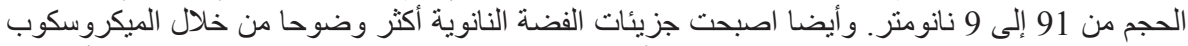

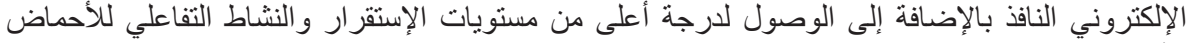

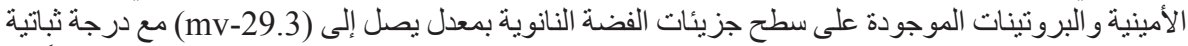

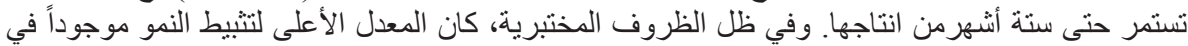

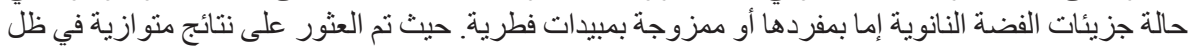

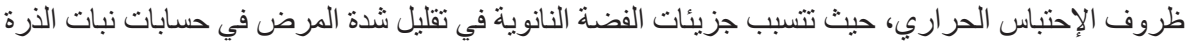

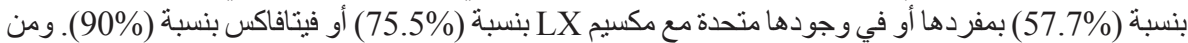
ثم يقتح هذا البحث إمكانيات جديدة في مجال استخدام الجسيمات النانوية في مقاومة الأمر اض اضناتئية.
\end{abstract}

